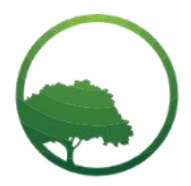

Research in Business \& Social Science

IJRBS VOL 10 NO 4 ISSN: 2147-4478

\title{
The meaning of cash flow management for the non-bank housing developers
}

\author{
(D) Mochammad Syarif Sofyan ${ }^{(a) *}$ (D) Unti Ludigdo ${ }^{(b)}$ (D) Aji Dedi Mulawarman ${ }^{(c)}$ \\ ${ }^{(a, c)}$ Accounting Departement, Faculty of Economics and Business, Brawijaya University, Jl. MT. Haryono 165, Malang, \\ Indonesia \\ (b) Professor, Accounting Departement, Faculty of Economics and Business, Brawijaya University, Jl. MT. Haryono 165, Malang, Indonesia \\ Crossref
}

\author{
A R TICLE INFO \\ Article history: \\ Received 08 May 2021 \\ Received in rev. form 25 May 2021 \\ Accepted 27 May 2021 \\ Keywords: \\ Cash Flow; Non-bank Housing; \\ Islamic Phenomenology; Sharia \\ JEL Classification: \\ L20, M41, R39
}

\begin{abstract}
A B S T R A C T
This study aims to investigate in more depth the meaning of cash flow management carried out by nonbank housing practitioners. This research, which uses Islamic phenomenology qualitative method, involves Muslim practitioner informants trying to operate their business to comply with various sharia provisions and scholar's informant who knows the non-bank housing business both in practice and the Islamic law. The findings indicate that cash flow means; (1) both material and non-material; (2) obedience to the implementation of cash flow management solutions in Islam; (3) creativity in cash flow management activities based on priority (compulsory, sunna, permissible); (4) justice obtained through muamalah contracts; (5) sharia oriented through the obligation to continue to communicate with the scholars. Thus, cash flow management does not only have material meaning, but also has other meanings which are strongly influenced by their beliefs.
\end{abstract}

(C) 2021 by the authors. Licensee SSBFNET, Istanbul, Turkey. This article is an open access article distributed under the terms and conditions of the Creative Commons Attribution (CC BY) license (http://creativecommons.org/licenses/by/4.0/).

\section{Introduction}

Changes in society that continue to move towards life to more following Islamic provisions are interesting to notice (Sutopo, 2010). The shift in consumer behavior, which makes spiritual value a priority in their decision-making (Yuswohady, 2018) and leads Muslims in Indonesia to buy products and transactions according to the rules of Islamic teaching, is an opportunity for producers.

Efforts to stay on track according to Islamic rules have not only been made by consumers, but have also been made by entrepreneurs. The preliminary interview with Mr. TS, owner of a hospital in Batu City, provided early proof of the importance of cash flow management. The motivation for changing business practices that do not involve bank financing is to obtain blessings from Allah SWT and avoid punishment in the form of hell due to usury. A preliminary interviewed was also conducted with Mr. A, the owner of a Malang City real estate sales agent. He stated that if you want to operate a legitimate business under Islamic law and bring you blessings, you must follow Islamic rules. At a glance, it is clear that they make changes in their business activities as a form of obedience to submit to Allah SWT to obtain blessings for all business activities carried out.

The housing industry is constantly evolving. The presence of Islamic banking in providing mortgages for consumers who want to avoid the prohibition on bank interest (Hidayat, 2017; Satria \& Setiani, 2018) still has several obstacles with the financing provided (H. Abdurrahman, 2016; Irma, Natalia, \& Kurniawan, 2016; Rahmawaty, 2007; Sulaiman, 2016; Suprihatin, 2015). As a result of these financing problems, many entrepreneurs have switched to non-banking schemes to meet community housing needs (Firmansyah \& Indika, 2017; Hidayah, Nawawi, \& Arif, 2018; Putri \& Hasan, 2017). They believe this scheme is more sharia-compliant (Firmansyah \& Gunardi, 2018) because it can avoid interest in conventional banks known as usury or margin in Islamic banks, which

* Corresponding author. ORCID ID: 0000-0003-0114-624X

(C) 2021 by the authors. Hosting by SSBFNET. Peer review under responsibility of Center for Strategic Studies in Business and Finance.

https://doi.org/10.20525/ijrbs.v10i4.1174 
claimed equivalent to bank interest (Irma et al., 2016). In contrast, the housing industry is has been known very close and even inseparable from the banking world, especially for its operational activities (Irma et al., 2016). Therefore, housing industry practitioners who use non-bank scheme are encouraged to manage their company's cash flow more carefully (Firmansyah \& Gunardi, 2018; Putri \& Hasan, 2017). Cash flows that are commonly known today are generally only understood as the activity of cash inflows and cash outflows within a certain period, especially those related to numbers. As a result, such cash flows only depict business events from the standpoint of material value, particularly in terms of the company's sustainability (going concern) and shareholder interests (Andreas, 2017; Bhandari \& Adams, 2017; Junaidi, 2015; Setyawati \& Amalia, 2018).

Based on the description above, this study aims to find out in more depth the meaning of cash flow management by non-bank housing developers whether it is the same as cash flow that is commonly known or there is another understanding that causes them to decide not to use assistance from third parties. The research of cash flow management by a non-bank developer is still rare, so this research is expected to provide an overview of cash flow suited to the character of Muslim entrepreneurs. To achieve the objective and answer the question, this study uses a qualitative research method through an Islamic phenomenological approach to understanding the existing consciousness of non-bank housing developers.

\section{Literatur Review}

\section{Islamic Cash flow}

Accounting is generally more oriented to return on investment and increase in assets (Alim, 2011). The existing sharia accounting is not much different from non-sharia accounting, which is to measure the success of an investment (Alsharif, Bataineh, \& Abo Aliqah, 2020; Umdiana \& Hapsari, 2016; Widowati, 2013), and today even focuses more on financial institutions (Adnan, 1997; Badreldin, 2019; Fajarwati \& Sambodo, 2010), whereas Islam regulates not only financial institutions but also a variety of other industries (Murtiyani, 2009). Mulawarman (2007, 2011, p. 14) observed that conventional cash flow statements originate from the concept of Cash Flow Accounting (CFA) developed due to dissatisfaction in measuring assets and income is very difficult, and the use of time value of money to evaluate investment plans related to the uncertain conditions surrounding them. The conventional cash flow statement based on the entity concept only stops for the interests of certain parties without spirituality, especially in the aspects of halal-haram, good-bad, true-false, and others (Mulawarman, 2011, p. 203). Related to this, Lee (1979) cites Fisher's opinion, which recognizes that the corporate entity is viewed as a vehicle for collecting profits and distributed them to individuals around the company (shareholders, creditors, suppliers, and employees).

Mulawarman (2011, p. 14) believes that the Islamic cash should have more than just facts and transactions of material nature, and offers a new concept regarding ma'isyah-based Islamic cash flow as an effort towards a cash flow that is based purely on the values and objectives of sharia. The management and development of the concept of cash flow can be done by applying spiritual intuition that uses the values and goals of Sharia law. Through these sharia values and objectives, it then continues to with the determination of the company's vision and mission, goals, and policies, including accounting policies (Mulawarman, 2011, p. 222).

\section{Non-bank Housing Industry}

The involvement of banks in the housing industry, in general, is inevitable as this industry requires a lot of capital, both in terms of land and housing purchases and the sales process (Irma et al., 2016). A non-bank mortgage program is a bit unusual in the real estate business, as there are generally always three parties involved in the homeownership process, namely the developer, either the conventional bank of sharia bank and the buyer (Hidayah et al., 2018).

The presence of housing developer that does not involve the banking sector is one of the efforts to provide homeownership solutions so that they are in the line of sharia, namely without usury (Firmansyah \& Indika, 2017; Hidayah et al., 2018; Putri \& Hasan, 2017). The developers of this system also affirm that there are no fines and also no confiscation of collateral if there are obstacles for consumers to meet their obligations to repay their debts through the mechanism of rescheduling installments. This mechanism further strengthens their tagline without usury and also does not violate the provisions of transactions in Islam (Irma et al., 2016).

\section{Research and Methodology}

Phenomenology as described by Moleong (2016, p. 16) is used in this study to explore awareness of the meaning of cash flow according to Muslim practitioner informants. A phenomenological approach is also used to describe an understanding of life experiences related to the concept of cash flow through data collection and to develop a description of "what" and "how" they live life experiences (Creswell, 2015, p. 105). Phenomenology also can be used to explore the meaning of cash flow by using Islam as the paradigm (Kamayanti, 2016, p. 150), it is called Islamic phenomenology (Niswatin, Triyuwono, Nurkholis, \& Kamayanti, 2014, 2015) or Tauhid phenomenology (Kamayanti, 2016, p. 160). Thus the selection of Islamic phenomenology is based on several considerations; (1) on organizations that are trying to operate their business to comply with various sharia provisions, namely organizations that define themselves as Islamic housing developer; (2) to explore the meaning of cash flow exists in non-bank housing practitioners who rely on various Islamic stipulations. Simply put, this study seeks to examine in depth the awareness of the meaning of cash flow in the business activities of its practitioners.

Owners or employees who are personally dealing with financial problems in their company are involved as informants because they know and feel the problems they are facing. Researchers maintain the confidentiality of informants by using the respective informants' 
initials. The involvement of scholar informant was motivated by the prohibition in Islam that only relies on logic without being based on the principle of extracting the correct provisions of Islamic law (Al-Faizin \& Nashr, 2018, p. 8). The list of informants in this study is as follows:

Table 1: list of informants

\begin{tabular}{|c|c|c|}
\hline No. & Name & Information \\
\hline 1 & Mr. K & Company owner 1 \\
\hline 2 & Mr. M & One of the company managers 1 \\
\hline 3 & Ms. D & Company finance officer 1 \\
\hline 4 & Mr. H & Company owner 2 \\
\hline 5 & Mr. S & Islamic economics expert, lecturer of Ushul Fiqh and Fiqh Muamalah \\
\hline
\end{tabular}

Source: as processed by the writer.

The main data in this study are the results of the epoche from interviews with entrepreneur/manager informants and a review of muamalah fiqh studies related to the phenomena observed with scholar informants. The interview contains two categories of questions: the first is related to actions of entrepreneur/manager informants about the cash management patterns they have implemented. Second, two groups of informants are asked knowledge questions. To get a better understanding of their cash handling patterns, questions for entrepreneur/manager informants are used. Questions for scholar informants are used to obtain Islamic law that they get from various scientific sources in Islam regarding cash management. In addition to data in the form of words and observations on informants' expressions, this study also uses data in the form of various literature on business based on Islamic provisions. Data processing did by adhering to the stages established by Niswatin et al. $(2014,2015)$ by first, exploring the truth of the kauniyah phenomenon, that is understanding and awareness derived from social phenomenon experienced by humans who are assumed to have an awareness that is bound to various Islamic provisions. This stage is carried out in three stages, the first is exploring the relationship between Noema and Noesis in the entrepreneur/manager informant. The second stage is conducting an intentional analysis to explore how noesis forms noema. The third step is to do the eidetic reduction, which involves incorporating all meaning processes that underlie whole pure consciousness. After digging into the facts of kauniyah, the next step is to explore the phenomenon of kauliyah through reviewing Al-Qur'an and Hadith, literature review on Islamic business provisions, and discussions with scholar informant who know the non-bank housing business both in practice and the Islamic law. The final stage is to synthesize the findings of the kauniyah and the kauliyah phenomenon.

Data Analysis

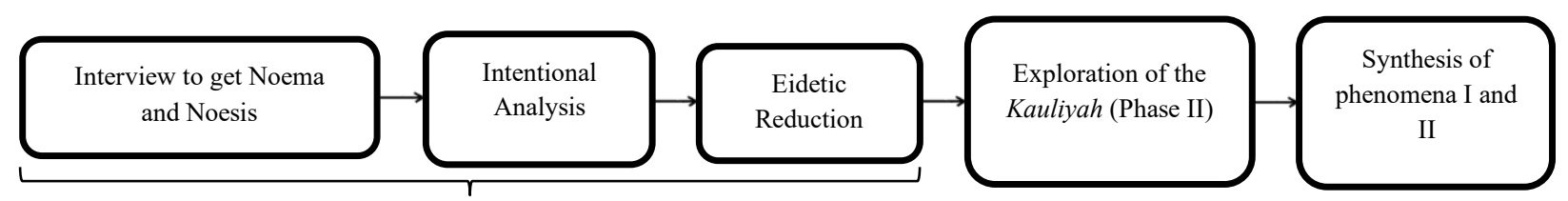

Exploration of the Kauniyah Phenomenon (Phase I)

Figure 1: Data analysis

\section{Results and Discussion}

\section{Cash Flow with both Material and Non-material Meaning}

The existence of a non-bank housing developer cannot separate from the environment in which it exists. This fact necessitates that they consider not only the needs of the company but also the society and the surrounding nature. Housing built without bank financing is required to pay attention to many aspects. An informant named Mr. K explained:

"Developers must consider all facets. However, not all things are always under the developer's control. It is important to pay careful attention to the environment."

Mr. H expressed a similar viewpoint, stating that "so that (the local community) can sense the project there" is an element of "feeling the need to share" the life of their project with the surrounding community through community empowerment in the project environment.

Noesis exploration on Mr. K and Mr. H's noema was carried out by questioning the reasons for the actions that not only pay attention to project success but also pay attention to the surrounding environment. The noesis that makes up the noema reveals that any land clearing for homes or plots would affect the surrounding environment. The intended impact arises because of the presence of a new community so that residents will share various facilities that were previously only used by them with those who came later. The affirmation of the noesis as expressed by Mr. K: 
"Buying land will have an impact on the environment. If we build housing there, which means it will have an impact on the neighbors. There is a new community in it and will affect the shared facilities."

The intentional analysis obtained then indicates that housing developments need not only focus on their project area construction but also the development of the area around the project since the land expansion affects humans and nature beyond the project area. So it stands to reason that the non-bank housing companies met not only pay attention to the success of their projects but also pay attention to the surrounding environment. Eidetic reduction generates awareness to constantly pay attention to the environment by informants because opening housing on land will have an impact on the natural environment and the surrounding community. The company must consider society and nature for the use of the facilities surrounding the project so that goodness can still be accessed by the people who have been there for a long time and who will inhabit the area, as well as nature as the place for facilities needed by humans.

Islam does not forbid or permit humans to do whatever they wish to acquiring and using property, but it does include guidelines. Mr. $\mathrm{S}$ clarified that in Islam, there is a rule for acquiring and using property known as istikhlaf:

"Property is a mandate from Allah to humans. Property and even the universe, the real owner is Allah... Allah as the real owner entrusts the treasure to humans."

Humans as the party entrusted with property must act under the wishes of the owner of the assets, as explained by Mr. S as follows:

"The implication is because the property is a deposit from Allah, then managing it must be under the will of Allah. Treasure is not our real property but belongs to Allah. When Allah says that usury is haram (prohibited), it is up to Allah because Allah is the Owner."

The increase in wealth in Islam is an activity that cannot be separated from its distribution and must go hand in hand. Increasing wealth in Islam is not an end in itself, but only an intermediate goal that will ultimately lead to an increase in the welfare of society as a whole (Manzilati, 2016, p. 372).

This fact feels very different when compared to the activities carried out by organizations that do not pay attention to Islamic provisions. If a company entity only viewed as a fictional figure that serves as a source of income for humans (Lee, 1979), and as a result, an overly egoistic behavior will emerge and only seek to maximize profits for the benefit of the company owner (stockholder) without having to pay attention to other obligations (Triyuwono, 2015, p. 203). Company in an Islamic standpoint is a mandate carried out by humans as khalifatullah fil 'ardh to create improvements for goodness through positive practices and establish a divine and harmonious community (Mulawarman, 2010). The company cannot be separated from the persons that form it and own it, in contrast to the entity concept. The company is the owner itself in muamalah activities, both individually and in groups, and has a role as part of the Muslim community to engage the distribution of wealth in the community.

In Islam, wealth is distributed by both economic and non-economic mechanisms. The economic mechanism operates through numerous muamalah practices aimed at profits (Manzilati, 2016, p. 374). Non-economic mechanisms are implemented without requiring a price for the gifts made, such as zakat, donations, waqf, alms, and others (Al-Faizin \& Nashr, 2018, p. 239; Ghofur, 2016, p. 290; Triono, 2017, p. 430) because there is an urge to get the reward from Allah SWT (Triono, 2017, p. 430). Thus, cash flow regulation in Islam has material and non-material value as well as being a mode of worship to Allah, The Ultimate Owner of all wealth (Budiman, 2014; Mulawarman, 2011, p. 13; Triyuwono, 2015, p. 356; Zulaekah, 2015).

\section{Management of Cash Flow as a Form of Obedience to the Solutions Given by Islam}

Proper cash flow management is very important for a housing company that is run without involving third-party financing. Mr. K explained this in the following statement:

"We don't use third parties to pay our obligations."

The noema that pays attention to cash flow management, also shown by Ms. D in the following explanation:

"It is very important because we are a sharia property developer. Without any assistance from third parties, namely banks. our capital from scratch. So the difference is like that from conventional. Thus cash flow is very important."

The presence of a noema prioritizes funding from internal sources of the company due to the noesis in the form of belief in the Islamic order, paying attention to the origin of the assets received and the expenditure of the assets, which can be seen in Mr. K's statement as follows:

"Our belief as Muslim businessmen is of course as conveyed by the hadith of the Prophet that every practice will be asked when in yaumul hisab (Day of Judgement)... the fourth is your treasure. It will be asked where you get it and where you spend."

The intentional analysis obtained shows that the cash flow management carried out by non-bank housing practitioners is due to an obligation in Islam to account for the assets received and their use. The eidetic reduction is in the form of awareness of managing cash flow appropriately because they do not use third-party financing as obedience to Islamic provisions. 
The obligations of a Muslim to work to find a part of the sustenance that He has prepared has revealed by Allah in the Quran Surat Al-Mulk: 15:

"It is He who made the earth tame for you - so walk among its slopes and eat of His provision - and to Him is the resurrection."

Allah does not allow humans to fulfill these obligations by doing them according to their own will without any direction from Him. Allah SWT is very concerned about the aspects of halalness in managing property such in the Al-Qur'an Surat Al-An'aam:141:

"...and do not act extravagantly; surely He does not love the extravagant."

Likewise with the information provided by the Prophet Muhammad in the following hadith:

"The feet of the son of Adam shall not move from before his Lord on the Day of Judgement, until he is asked about five things: about his life and what he did with it, about his youth and what he wore it out in, about his wealth and how he earned it and spent it upon, and what he did with what he knew."

From Al-Qur'an and hadith above, managing assets, including money entrusted by Allah to every Muslim, is not just about how to get it, but also in terms of spending it. Cash flow which is understood by Muslim practitioners of Islamic housing apart from being a solution in managing incoming and outgoing money is also a part of Islamic provisions that must pay attention to its halal and haram aspects.

\section{Priority in Cash Flow, Creativity Amid the Threat of Usury}

Management of cash flow in the non-bank housing industry requires creativity in determining cash management priorities. The subsequent description demonstrates noema in creativity:

"Leader's creativity skills are tested there. How a leader can organize such limited cash flow."

Islam does not forbid or permit humans to do whatever they wish to acquiring and using property, but it does include guidelines. Mr. $\mathrm{S}$ clarified that in Islam, there is a rule for acquiring and using property known as istikhlaf:

"Property is a mandate from Allah to humans. Property and even the universe, the real owner is Allah... Allah as the real owner entrusts the treasure to humans."

Through deeper exploration, the creativity in question is related to a person's ability to find solutions to keep cash flow healthy, as explained by Mr. K:

"That's what I mean his business skills will be tested. The ability of a person to find a solution to how cash flow is healthy... We assume that even if we want to pay for what we need, for example, one year, we will still assume that it must be paid immediately, related to obligations."

Mr. K expressed the effort to maintain a stable cash flow by adjusting all expenses with the incoming funds (cash) so that all expenses are carried out according to the period that comes as part of the akad (deal) that has been made with various parties. Mr. K provides adjustment guidelines regarding the most important expenditure to be fulfilled, namely everything that has the status of an obligation then the others by saying "Complete the obligation first, then the others".

Noema and creativity noesis in cash management was also expressed by Mr. H, who was met when he was having financial problems, by expressing his regret because he was wrong in managing cash and said "it's my fault." Because of the duties, he fulfilled them with personal funds because he was concerned about sins resulting from failure to meet commitments to third parties.

"It is an obligation. I feel guilty if I have money but said don't have."

Creativity is needed because temptation can be present anytime to them to do activities that contain usury, such as Mr. K's statement:

"If a developer cannot stand the temptation, it is horrible. Some consumers can say they have money, for example, 100 million rupiah. Then he made an ownership certificate (SHM), and I brought it to the bank."

Intentional analysis regarding this phenomenon that informant feels the need to have creativity in managing cash flow so that he is not easily tempted by conditions that can plunge them into usury activity. Eidetic reduction according to the informant that the housing business without a bank requires creativity in managing cash through determining priority, especially spending with great attention to the obligations that arise so as not to be easily tempted to be involved in activities related to usury. The priority of using money in Islam is obtained through interviews with Mr. S. The priority scale in spending a Muslim's money can be divided into three activities so that the money spent is worth a blessing, namely wajib (compulsory), sunnah, and mubah (permissible).

"The priority for the expenditure is what is wajib, then what is sunnah, then what is mubah. Paying the debt is compulsory, shodaqoh is sunnah. The Zakat on trade is compulsory if he is in the business of buying and selling, he is obliged to pay zakat for good, which is compulsory. But if he issues shodaqoh it is sunnah, it is not compulsory." 
Determination of profit, which ultimately also affects cash receipts, has no quantitative limitations but does have qualitative ones, that is must be halal (Al-Jawi, 2013; Fachrudin, 2018) based on surat An-Nissa': 29 and even the hadith of the Prophet Muhammad by the case of Urwah's purchase of a goat. Mr. S conveyed this in the following explanation:

"There are no quantitative limitations; rather, there are qualitative ones; the main thing is that the profit is halal (legitimate). As a result, there is no quantitative limitation, for example, it is limited to a maximum of $30 \%$ of the cost; it does not exist. Profits of up to $100 \%$ are permitted."

Through these various explanations, cash flow management needs to pay attention to the priority scale of spending on money owned, while its acquisition is bounded by provisions relating to the quality of money earned. Management in the form of receiving and using money is carried out following Islamic provisions because even though the money belongs to persons or organizations, they are not permitted to use it openly and must adhere to the terms of its use. That is base on the understanding that a Muslim must-know rules of Islamic law regarding these actions before committing them, whether the law is mubah, fardlu, mandub, haram, or makruh through extracting various sources from the Al-Qur'an, Sunnah, Ijma' and qiyas (Ismail, 2011, p. 85).

Based on the explanation of practitioner informants and scholars who prioritize compulsory activities and then carry out other activities, the priority of shopping activities can be divided into several levels, namely compulsory, sunnah, and permissible (Triono, 2017, p. 378). According to the explanation above, cash flow management is creativity by paying attention to the priority scale of expenditure by categorizing it as mandatory, sunnah, and permissible. Determining the priority scale is an integral part of the money obtained by paying attention to its halal aspects so that cash management would be blessed.

\section{Justice Meaning}

Companies that identify themselves with the term "sharia" must strictly base their business activities on Islamic provisions, considering the various Islamic laws related to their operations. One of the concerns is to carry up the cash inflow and outflow activities below the terms of the akad (contract) regulated in Islam, such as Mr. K's statement below:

"The most important thing is that we have a perfect akad with the landowner."

Noema, the existence of the contract is not only in buying and selling activities, even in every business activity that is carried out. Since forming the company, Mr. K has used the syirkah, as evident in his statement below:

"I used syirkah, that is syirkah of energy, actually contributing energy together."

When hiring employees, the contract is the ijarah:

"Because of the ijarah contract, they work under the assigned work. They get the rights as promised if the work is done correctly. Either the company is experiencing a loss, it is outside (their responsibility). The ijarah contract is different from the syirkah treaty."

As evidence of the importance of contracts, one of the educational materials for potential customers is also to pay attention to agreements and their consequences. Mr. K stated that if you do not pay attention to the contract in the transaction, then any item whose status is obtained will be unclear and can even become illegitimate so that it has the potential to be haram and lead to sin. The unclear status of the property received is due to not following the provisions of the akad in Islam because it is the akad that determines the value of a muamalah transaction to be rewarded or sinful. Such as Mr. K's statement below:

"Because for a Muslim, every step in this world is only two possibilities, whether it is worth a reward or a sin. The akad determines the value of the muamalah transaction."

Ms. D and Mr. M also understood the linkages to the akad. Ms. D said, "Recorded the project was canceled. Yes, that's a consequence, not a loss" when explaining that the company must accept if the down payment that has cannot be withdrawn when they cancel the sale and purchase. Mr. M also added, "yes the term is indeed risk". They not only pay attention to usury but also to akad that are not following Islamic provisions. The policy without penalty and confiscation of consumer collateral (if any) also comes from linkages to the akad. One of the goodness that will obtain by various parties who performing transactions by adhering to the terms of the akad in Islam is the establishment of justice because everyone will bound by the same rules that come from Islam. Mr. K explained the meaning of justice in the following statement:

"So we are equally fair. There is a justice aspect to this scheme as it does not harm consumers."

Intentional analysis obtained is, akad for informants in housing business activities without a bank will determine whether the transactions they are doing are worth a reward or a sin, and provide justice for all parties. The eidetic reduction obtained is that the informant realizes that every transaction carried out using a akad under Islamic provisions will result in justice for all parties, whether done with fellow owners through syirkah, ijarah with employees, or with external parties through buying and selling activities. The akad will determine whether the property they get becomes lawful and results in rewards or whether it becomes haram and results in sin.

The various business stages that are carried out always follow the terms of the akad according to the type of transaction they are conducting. An akad based on the term sharia is the linkage of ijab and qabul under sharia and has legal consequences on the object 
of the akad (Mahmud, 2009, p. 36). Zubair \& Hamid (2016) explains that the akad is a sharia transaction frame or a form of agreement that can be used as an essential source of engagement in sharia because it contains rights and obligations for each party. An akad is also a form of facility that exists in Islam for various business activities for humans to fulfill needs that they cannot meet themselves without the help of others and is a social tool in human civilization that supports their life as a social being (Budiwati, 2017). Justice in the akad is seen through certainty regarding the transfer of ownership and also through the khiyar concept (Hafizah, 2012; Mahmud, 2009, p. 309), which is not in favor of the interests of one party only, but all parties involved will be bounded by Islamic provisions, and have no opportunity to cheat to the other party. Justice in the akad was guaranteed by Islam because, as conveyed by Sayyid Sabiq that an akad will automatically flaw and become invalid according to Islamic law if there is ikrah (coercion), ghalath (misunderstanding), khilabah (deceptive inducement), and ikhtilat al tanfidz (a later defect) (Rahmawati, 2011).

\section{Sharia Oriented}

Non-bank housing activities carried out under various provisions of Islamic law cannot be separated from scholars. The role of scholars feels very deep when there are scholars who argue that the industry they run so far still has mistakes. They studied the opinions of scholars and followed them by changed the akad used previously. The following is Mr. K's statement:

"I am following the opinion accepted by the DPS (Developer Property Syariah community) because the transactions made by DPS, as I understand, always come from Al-Qur'an and As-Sunnah references."

When it was verified whether to keep using the original akad or replacing it with a new one, Mr. H also said, "yes, it has been replaced". The noema, that is the behavior of the informants who follow the opinions of other people whom they consider as scholars in carrying out business activities because they realize that they cannot understand the contents of the Al-Qur'an and also the explanations of the Al-Qur'an that are spread in the Hadith. The admission of entrepreneurs who do not have more knowledge than the ulama is evident in Mr. K's statement below:

"The source of Islamic law is Al-Qur'an and As-Sunnah, which can only be understood only by people who understand the Al-Qur'an and hadith. If I take it directly from the Al-Qur'an and As-Sunnah, there will likely be many mistakes because I don't understand the knowledge."

Informants believed that they should follow the opinion of scholars who were believed to be able to understand Islamic law in the context of their business, as shown in the following statement:

"Scholars have the importance of taking hadith or sources of sharia law which they know are strong. So we only use them because we don't know about them."

Noesis explained that Noema follows scholars, which means scholars understand more about sharia law about the Islamic law of non-bank housing than business practitioners. The intentional analysis follows the opinion of the scholars is, the informant makes the scholars as a source of information on sharia law because he realizes that he does not have in-depth knowledge of the various source of Islamic law as well as the scholars. The eidetic reduction of this phenomenon is that the informant felt the need to follow the opinions of scholars who he believed understood Islamic law related to business activities which would later have consequences for cash inflows and outflows to have a blessing. Actions based on the provisions of the Sharia become visible when they decide to convert the used akad from the istishna' into an ordinary purchase and sale. Initially, they used the istishna' and lasted a long time. Using that contract carries less financial risk when compared to common buying and selling. From a cash flow turnover perspective, it is more flexible. They do not have to provide the product in advance by using the istishna'. When the opinion of the scholar emerged that they were considered to have a foundation of Islamic law and a better understanding of the facts, they changed their business process in the opinion of the scholar using the usual sales and purchase contract. By using the new contract, they are obliged to provide products in advance so that they can carry out sale and purchase transactions even though the provision of these products requires sacrifices, especially funding to produce the products to be sold.

Business activity cannot be separated from various Islamic provisions because of the position of Islam itself, which serves as the solution to the problems of human life. The solution is achieved by studying the problems one is faced with and then studying the laws of Islam through understanding the Islamic sources texts which are related to them (Ismail, 2011, p. 160). Every Muslim believes that he will be responsible for all actions in the world. On this basis, every Muslim should adapt his actions to Islamic laws, that is, to all commands and prohibitions of Allah SWT as He says in Al-Qur'an Surat Al Hasyr: 7:

"And whatever the Messenger has given you - take; and what he has forbidden you - refrain from."

Any Muslim who acts to meet his/her needs must know Allah's law regarding that act before committing it (Ismail, 2011, p. 52). In other words, every activity undertaken will be sharia-oriented. Sharia law is an exclamation or words from As Shari' (Allah is the Lawmaker) related to the actions of servants, whether in the form of demands, giving choices, or stipulating something like a legal regulator (Ali, 2015; Irwansyah, 2018; Triono, 2020, p. 88). Sharia-oriented activities that follow the opinions of scholars who have a stronger legal base are one way of keeping business within the Sharia law. Sharia-oriented, therefore, is a continuous effort to maintain attachment to the provisions of the Sharia by actively communicating with those who know more about Islamic law with scholars. Likewise, accounting in the Hasabah sense, which functions as an information system, measuring tool, and accountability 
for human deeds (acts) during life (Batubara, 2019; Septyan \& Julianto, 2017), needs to be developed in the same perspective as surrounding commercial activities.

Exploring Islamic law requires various abilities, especially those related to the sources of Islamic law, such as knowledge of verses relating to the law in the Qur'an, knowing the reasons for the revelation of the verse, knowing about nasikh and mansukh, knowing As-Sunnah, knowing the facts of business problems, and so on (Has, 2013). If there is a problem in the business world, a Muslim should ask about this problem to scholars who understand the problem. Nasution (2014) explained that scholars with their knowledge have a very high fear to Allah and inherit the main characteristics of the prophets in believing in the oneness of Allah, practicing all the commands of Allah, and guiding and helping people solve their various problems according to the teachings of Allah. Thus, cash flow management carried out through a view that considers Islam as the source of truth must constantly maintain its attachment to sharia provisions through active communication with scholars.

\section{Meaning of Cash Flow Management}

Various discussions and results obtained regarding the meaning of cash flow management by housing industry practitioners that do not involve financing from banks can be simplified in the following table:

Table 2: Practitioners' Meaning of Cash Flow

\begin{tabular}{llll}
\hline The Meaning & Noema & Noesis & Intentional Analysis \\
\hline Material and & Developers must consider all & Buying land will have & Informants need not only focus \\
non-material & facets. However, not all things & an impact on the on their project area \\
at once & are always under the & environment. If we construction but also the \\
& developer's control. It is build housing there, development of the area around \\
& important to fpay careful which means it will the project since the land \\
& attention\} to the environment. & have an impact on the expansion affects humans and \\
& & neighbors & nature beyond the project area
\end{tabular}

\begin{tabular}{llll}
\hline Obedience & We \{don't use third parties\} to \\
pay our obligations & $\begin{array}{l}\text { Our belief as Muslim cash flow management carried } \\
\text { businessmen is every out by non-bank housing } \\
\text { practice will be practitioners is due to an } \\
\text { asked... the fourth is obligation in Islam to account } \\
\text { your treasure. It will be for the assets received and their } \\
\text { asked where you get it use } \\
\text { and where you spend }\end{array}$ \\
\hline Creativity & $\begin{array}{l}\text { Leader's \{creativity\} skills are } \\
\text { tested there. How a leader can } \\
\text { organize such limited cash }\end{array}$ & $\begin{array}{l}\text { The ability of a person Informants feel the need to have } \\
\text { to find a solution to creativity in managing cash } \\
\text { how cash flow is flow so that he is not easily }\end{array}$ \\
& hlow & $\begin{array}{l}\text { healthy... Complete the tempted by conditions that can } \\
\text { obligation first, then plunge them into usury activity } \\
\text { the others }\end{array}$
\end{tabular}

Justice The most important thing is Akad determines the that we have a perfect $\{\mathrm{akad}\} \quad$ value of the muamalah with the landowner.

transaction... So we are equally fair. There is a justice aspect to this scheme as it does not harm consumers

\begin{tabular}{ll}
\hline Sharia & $\{$ I am following the opinion $\}$ \\
Oriented & accepted by the DPS because \\
the transactions made by DPS, \\
as I understand, always come \\
from Al-Qur'an and As- \\
Sunnah references.
\end{tabular}

Scholars have the Informant makes the scholars as
importance of taking a source of information on hadith or sources of sharia law because he realizes sharia law which they that he does not have in-depth know are strong. So we knowledge of the various only use them because source of Islamic law as well as we don't know about the scholars them

\section{Eidetic Reduction}

The awareness to always pay attention to the environment by informants because opening housing on land will have an impact on the natural environment and surrounding communities in the form of natural facilities that will be used together with the new community

awareness of managing cash flow appropriately because they do not use third-party financing as obedience to Islamic provisions

Housing business without a bank requires creativity in managing cash through determining priority, especially spending with great attention to the obligations that arise so as not to be easily tempted to be involved in activities related to usury.

Informant realizes that every transaction carried out using a akad under Islamic provisions will result in justice for all parties, whether done with fellow owners through syirkah, ijarah with employees, or with external parties

Informant felt the need to follow the opinions of scholars who he believed understood Islamic law related to business activities which would later have consequences for cash inflows and outflows to have a blessing. 


\section{Conclusions}

Cash flow is very important especially for non-bank housing because they have to be independent in financing their various business operations. Cash flow management is interpreted not simply as a material meaning that arises from the business aspect but also as other meanings that come from various rules in Islam that have influenced their consciousness. There are five meanings of cash flow management for the non-bank housing developers: namely cash flow have material and non-material, cash flow as a form of obedience to the solutions given by Islam, cash flow as creativity amid the threat of usury through the existence of priority, justice, and sharia oriented. In this way, they have the confidence that their cash flow management will be blessed by God, even if it is against the customs in their industry, and requires even greater efforts to maintain cash liquidity so that their business can continue. The result of the study provides an overview of cash flow suited to the character of Muslim entrepreneurs, especially in the non-bank housing industry. This research shows that with proper cash flow management based on the belief in Islam, companies that have been known to be inseparable from the banking world are still able to move and even develop.

This research still has several limitations. Among these limitations are the limited number of informants who use this kind of business concept in the housing industry, accompanied by an adequate understanding of various Islamic provisions in the business world. Second, there are limitations to discussing aspects of business fiqh related to the non-bank housing industry as there are not many studies that specifically discuss the various Islamic regulations regarding this industry.

Subsequent accounting research also needs to pay attention to aspects of the religiosity of entrepreneurs, especially Muslim entrepreneurs. Subsequent accounting research also needs to pay attention to aspects of the religiosity of entrepreneurs, especially Muslim entrepreneurs. That research is not only concerned with how business transactions take place, but also the background of the implementation of a business transaction by Muslim entrepreneurs who want to be ruled by Islamic law. This research still looks at a certain muamalah opinion by a certain business community, so the next research can also be carried out on informants who have different Islamic views because of the very diversity of Islamic opinions in Islam. This of course will add to the treasury of Islamic accounting in the future.

\section{References}

Abdurrahman, H. (2016). Rapor Merah Bank Syariah Kritik atas Fatwa Produk Perbankan Syariah. Bogor: Al-Azhar Press.

Adnan, M. A. (1997). The Shari'ah, Islamic Banks and Accounting Concept. Jurnal Akuntansi Dan Auditing Indonesia, 1(1), 47-80. Retrieved from https://journal.uii.ac.id/JAAI/article/view/11034

Al-Faizin, A. W., \& Nashr, A. (2018). Tafsir Ekonomi Kontemporer: Menggali Teori Ekonomi Dari Ayat-ayat Al-Qur'an. Jakarta: Gema Insani.

Al-Jawi, M. S. (2013). Batas Maksimal Laba Perdagangan, Adakah? Retrieved March 8, 2021, from konsultasi.wordpress.com website: https://konsultasi.wordpress.com/2013/11/12/batas-maksimal-laba-perdagangan-adakah/

Ali, M. N. (2015). Perbuatan dan Tanggungjawab Hukum dalam Konsep Ushul Fiqh. Istinbath : Jurnal Hukum, 12(1), 20-38. Retrieved from https://ojs.metrouniv.ac.id/index.php/istinbath/article/view/573

Alim, M. N. (2011). Akuntansi Syariah Esensi , Konsepsi , Epistimologi, Dan Metodologi. Jurnal Investasi, 7(2), 154-161. Retrieved from https://journal.trunojoyo.ac.id/infestasi/article/view/498

Alsharif, B. M., Bataineh, T. M., \& Abo Aliqah, K. M. (2020). Cash Flows and Earnings for Share in Islamic Banks: Jordanian Evidence. International Journal of Business and Management, 15(12), 15-24. https://doi.org/10.5539/ijbm.v15n12p15

Andreas. (2017). Analysis of Operating Cash Flow to Detect Real Activity Manipulation and Its Effect on Market Performance. International Journal of Economics and Financial Issues, 7(1), 524-529. Retrieved from https://www.econjournals.com/index.php/ijefi/article/view/3981

Badreldin, A. (2019). Transparency Problems in Cash Flow Transformation and Reserves Management in Islamic Investment Accounts. Journal of Islamic Finance, 8(2), 1-9. Retrieved from https://journals.iium.edu.my/iiibfjournal/index.php/jif/article/view/310

Batubara, Z. (2019). Akuntansi Dalam Pandangan Islam. JAS (Jurnal Akuntansi Syariah), 3(1), 66-77. https://doi.org/https://doi.org/10.46367/jas.v3i1.163

Bhandari, S. B., \& Adams, M. T. (2017). On the definition, measurements, and use of the free cash flow concept in financial areporting and analysis: A review and recommendations. Journal of Accounting and Finance, 17(1), 11-19. Retrieved from http://www.na-businesspress.com/JAF/BhandariSB_Web17_1_.pdf

Budiman, A. (2014). Kapitalisme Ekonomi Syariah. An-Nisbah: Jurnal Ekonomi Syariah, 1(1), $47-71$. https://doi.org/10.21274/an.2014.1.1.47-71

Budiwati, S. (2017). Akad Sebagai Bingkai Transaksi Bisnis Syariah. Jurnal Jurisprudence, 7(2), $152-159$. https://doi.org/10.23917/jurisprudence.v7i2.4095

Creswell, J. W. (2015). Qualitative Inquiry \& Research Design: Choosing Among Five Approaches (Ke-3; A. L. Lazuardi, Trans.). Yogyakarta: Pustaka Pelajar.

Fachrudin, F. (2018). Kajian Teori Laba Pada Transaksi Jual Beli Dalam Fiqh Mu’āmalah (Studi Komparasi Teori Laba Ekonomi Konvensional). Ad Deenar: Jurnal Ekonomi Dan Bisnis Islam, 1(01), 68-74. https://doi.org/10.30868/ad.v1i01.228 
Fajarwati, D., \& Sambodo, S. D. (2010). Pengkajian Tentang Penyusunan dan Penyajian Laporan Keuangan Pada Lembaga Keuangan Syariah. JRAK: Jurnal Riset Akuntansi Dan Komputerisasi Akuntansi, 1(2), 15-37. Retrieved from http://jurnal.unismabekasi.ac.id/index.php/jrak/article/view/127

Firmansyah, E. A., \& Gunardi, A. (2018). A New Paradigm in Islamic Housing: Non-Bank Islamic Mortgage. Al-Iqtishad: Jurnal Ilmu Ekonomi Syariah, 10(2), 313-324. https://doi.org/10.15408/aiq.v10i2.7274

Firmansyah, E. A., \& Indika, D. R. (2017). Kredit Pemilikan Rumah Syariah Tanpa Bank: Studi di Jawa Barat. Jurnal Manajemen Teori Dan Terapan. Journal of Theory and Applied Management, 10(3), 223-230. https://doi.org/10.20473/jmtt.v10i3.6541

Ghofur, R. A. (2016). Teori Disribusi dalm Sistem Ekonomi Islam. In Fordebi, Adesy, Ekonomi dan Bisnis Islam: Seri Konsep dan Aplikasi Ekonomi dan Bisnis Islam (pp. 274-297). Jakarta: Rajawali Pers.

Hafizah, Y. (2012). Khiyar sebagai Upaya Mewujudkan Keadilan dalam Bisnis Islami. At-Taradhi: Jurnal Ilmu Ekonomi, 3(2), 165171. Retrieved from https://jurnal.uin-antasari.ac.id/index.php/taradhi/article/view/571

Has, A. W. (2013). Ijtihad Sebagai Alat Pemecahan Masalah Umat Islam. Epistemé: Jurnal Pengembangan Ilmu Keislaman, 8(1), 89-112. https://doi.org/10.21274/epis.2013.8.1.89-112

Hidayah, M. R., Nawawi, K., \& Arif, S. (2018). Analisis Implementasi Akad Istishna Pembiayaan Rumah (Studi Kasus Developer Property Syariah Bogor). Jurnal Ekonomi Islam, 9(1), 1-12. Retrieved from https://journal.uhamka.ac.id/index.php/jei/article/view/1288

Hidayat, G. (2017). Analisis Faktor-Faktor Yang Mempengaruhi Keputusan Permintaan KPR Pada Bank Syariah Di Kabupaten Sumedang. Coopetion, VIII(2), 129-137. Retrieved from https://ikopin.ac.id/jurnal/index.php/coopetition/article/view/32

Irma, A. H., Natalia, A. P., \& Kurniawan, D. E. (2016). Kepatuhan Terhadap Nilai-nilai Syariah Islam Pada Kredit Properti Syariah. The International Conference on Economics, Business and Social Science (ICEBUSS), 1-16. Malang, Jawa Timur. Retrieved from http://icebuss.org/paper/207.pdf

Irwansyah, S. (2018). Perbuatan dan Pertanggungjawaban Hukum dalam Bingkai Ushul Fikih. Tahkim (Jurnal Peradaban Dan Hukum Islam), 1(1), 88-101. https://doi.org/10.29313/tahkim.v1i1.3223

Ismail, M. (2011). Fikrul Islam : Bunga Rampai Pemikiran Islam. Bogor: Al-Azhar Press.

Junaidi. (2015). Laba dan Arus Kas dalam Memprediksi Laba dan Arus Kas Masa Mendatang dan Pola Harga Saham. Jurnal Akuntansi Dan Keuangan, 17(2), 97-107. https://doi.org/10.9744/jak.17.2.97-107

Kamayanti, A. (2016). Metodologi Penelitian Kualitatif Akuntansi: Pengantar Religiositas Keilmuan. Jakarta Selatan: Yayasan Rumah Peneleh.

Lee, T. A. (1979). The Contribution Of Fisher To Cash Flow Accounting. Journal of Business Finance \& Accounting, 6(3), 321330. https://doi.org/10.1111/j.1468-5957.1979.tb01093.x

Mahmud, Y. A. (2009). Al-Buyu' al-Qadimah wa al-Mu'ashirah wa al-Burshat al-Mahaliyyah wa ad-Duwaliyyah (Y. Abdurrahman, Trans.). Bogor: Al-Azhar Press.

Manzilati, A. (2016). Wealth System dalam Islam. In Fordebi, Adesy, Ekonomi dan Bisnis Islam: Seri Konsep dan Aplikasi Ekonomi dan Bisnis Islam (pp. 364-393). Jakarta: Rajawali Pers.

Moleong, L. J. (2016). Metodologi Penelitian Kualitatif (Revisi). Bandung, Indonesia: PT. Remaja Rosdakarya.

Mulawarman, A. D. (2007). Menggagas Laporan Arus Kas Syari'ah Berbasis Ma'isyah: Diangkat Dari Habitus Bisnis Muslim $\begin{array}{lllll}\text { Indonesia. } & S N A & \text { Makassar. } & \text { Retrieved } & \text { from }\end{array}$ http://digilib.mercubuana.ac.id/manager/t!@file_artikel_abstrak/Isi_Abstraksi_352320727076.pdf

Mulawarman, A. D. (2010). Integrasi Paradigma Akuntansi: Refleksi atas Pendekatan Sosiologi dalam Ilmu Akuntansi. Jurnal Akuntansi Multiparadigma, 1(1), 155-171. https://doi.org/10.18202/jamal.2010.04.7086

Mulawarman, A. D. (2011). Akuntansi Syariah Teori, Konsep dan Laporan Keuangan. Jakarta: Bani Hasyim Press \& E. Publishing.

Murtiyani, S. (2009). The Historical fact and development concept of shariah accounting. Jurnal Mukaddimah, XV(26), 43-58. Retrieved from http://digilib.uin-suka.ac.id/8626/1/SITI MURTIYANI THE HISTORICAL FACT AND DEVELOPMENT CONCEPT OF SHARIAH ACCOUNTING.pdf

Nasution, M. Y. (2014). Peran Strategis Ulama dalam Pengembangan Ekonomi Syariah. Human Fallah, 1(1), 17-28. Retrieved from http://jurnal.uinsu.ac.id/index.php/humanfalah/article/view/161

Niswatin, Triyuwono, I., Nurkholis, \& Kamayanti, A. (2014). Islamic Values of Islamic Bank Underlying Performance Assessment. Research Journal of Finance and Accounting, 5(24), 106-114. Retrieved from https://www.iiste.org/Journals/index.php/RJFA/article/view/18499

Niswatin, Triyuwono, I., Nurkholis, \& Kamayanti, A. (2015). Konsep Dasar Penilaian Kinerja Bank Syariah. Simposium Nasional Akuntansi (SNA) XVIII. Medan. Retrieved from http://lib.ibs.ac.id/materi/Prosiding/SNA XVIII/makalah/075.pdf

Putri, C. R. S., \& Hasan, D. B. N. (2017). Analisis Penerapan Konsep Bisnis Syariah pada Jual Beli Rumah (Studi Kasus di Developer Property Syariah D'Ahsana Mojokerto) (Universitas Trunojoyo Madura). Universitas Trunojoyo Madura. Retrieved from https://pta.trunojoyo.ac.id/welcome/detail/130721100070

Rahmawati. (2011). Dinamika Akad dalam Transaksi Ekonomi Syariah. Al-Iqtishad: Journal of Islamic Economics, 3(1), 19-34. https://doi.org/10.15408/aiq.v3i1.2494

Rahmawaty, A. (2007). Ekonomi Syari'ah: Tinjauan Kritis Produk Murabahah dalam Perbankan Syari'ah di Indonesia. La_Riba, 1(2), 187-203. https://doi.org/10.20885/lariba.vol1.iss2.art3 
Satria, M. R., \& Setiani, T. (2018). Analisis Perbandingan Pemberian Kredit Pemilikan Rumah (KPR) Pada Bank Konvensional Dengan Pembiayaan Murabahah (KPR) Pada Bank Syariah. Amwaluna: Jurnal Ekonomi Dan Keuangan Syariah, 2(1), 105118. https://doi.org/10.29313/amwaluna.v2i1.2880

Septyan, K., \& Julianto, W. (2017). Urgensi Fiqih Muamalah dalam Mata Kuliah Akuntansi Syariah. JAS (Jurnal Akuntansi Syariah), 1(2), 300-310. Retrieved from https://ejournal.stiesyariahbengkalis.ac.id/index.php/jas/article/view/119

Setyawati, I., \& Amalia, R. (2018). The Role of Current Ratio, Operating Cash Flow and Inflation Rate in Predicting Financial Distress: Indonesia Stock Exchange. Jurnal Dinamika Manajemen, 9(2), 140-148. https://doi.org/10.15294/jdm.v9i2.14195

Sulaiman, S. (2016). Penyimpangan Akad Murābahah Pada Perbankan Syariah di Indonesia. Iqtishodia: Jurnal Ekonomi Syariah, 1(2), 1-16. Retrieved from http://ejournal.alqolam.ac.id/index.php/iqtishodia/article/view/61

Suprihatin, S. (2015). Otentisitas Konsep al-Murâbahah Di Bank Syariah. AHKAM: Jurnal Ilmu Syariah, 15(1), 73-80. https://doi.org/10.15408/ajis.v15i1.2850

Sutopo, O. R. (2010). Beragam Islam, Beragam Ekspresi: Islam Indonesia dalam Praktik. MASYARAKAT: Jurnal Sosiologi, 15(2), 85-97. https://doi.org/10.7454/mjs.v15i2.4999

Triono, D. C. (2017). Ekonomi Islam Madzhab Hamfara - Jilid 1 : Falsafah Ekonomi Islam (Revisi). Yogyakarta: Irtikaz.

Triono, D. C. (2020). Membangun Bisnis Syari'ah 01. Yogyakarta: Daaruts Tsaqofi.

Triyuwono, I. (2015). Akuntansi Syariah: Perspektif, Metodologi, dan Teori (Ke-2). Jakarta: Rajawali Pers.

Umdiana, N., \& Hapsari, D. P. (2016). Analisis Penaruh Arus Kas Bersih dan Laba Terhadap Saham Syariah. Jurnal Akuntansi, 3(1), 16-23. Retrieved from https://e-jurnal.lppmunsera.org/index.php/Akuntansi/article/view/196

Widowati, E. (2013). Pengaruh Labar Akuntansi dan Arus Kas Terhadap Return Saham Syariah yang Terdaftar di Jakarta Islamic Index Tahun 2007-2008. Jurnal Ilmiah Wahana Akuntansi, 8(2), 137-148. Retrieved from http://journal.unj.ac.id/unj/index.php/wahana-akuntansi/article/view/859

Yuswohady. (2018). Perkembangan Pasar Bisnis Syariah. Retrieved October 11, 2018, from economy.okezone.com website: https://economy.okezone.com/read/2018/05/20/320/1900477/perkembangan-pasar-bisnis-syariah?page=1

Zubair, M. K., \& Hamid, A. (2016). Eksistensi Akad Dalam Transaksi Keuangan Syariah. Diktum: Jurnal Syariah Dan Hukum, 14(1), 45-54. Retrieved from http://almaiyyah.iainpare.ac.id/index.php/diktum/article/view/222

Zulaekah, Z. (2015). Norma Hak Milik Dalam Al-Qur'an. IQTISHADIA: Jurnal Ekonomi \& Perbankan Syariah, 1(2), 176. Retrieved from http://ejournal.iainmadura.ac.id/index.php/iqtishadia/article/view/480

Publisher's Note: SSBFNET stays neutral with regard to jurisdictional claims in published maps and institutional affiliations.

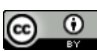

(C) 2021 by the authors. Licensee SSBFNET, Istanbul, Turkey. This article is an open access article distributed under the terms and conditions of the Creative Commons Attribution (CC BY) license (http://creativecommons.org/licenses/by/4.0/).

International Journal of Research in Business and Social Science (2147-4478) by SSBFNET is licensed under a Creative Commons Attribution 4.0 International License. 